\title{
476 doanh nghiệp Việt được tôn vinh HVNCLC
}

minhmeo

(Congluan.vn) - Tối ngày 25/2, Lễ tôn vinh 476 Doanh nghiệp Hàng Việt Nam chất luọng cao năm 2014 (DN HVNCLC) đãa được tổ chức long trọng tại Trung tâm hội nghị White Palace, TP.HCM.

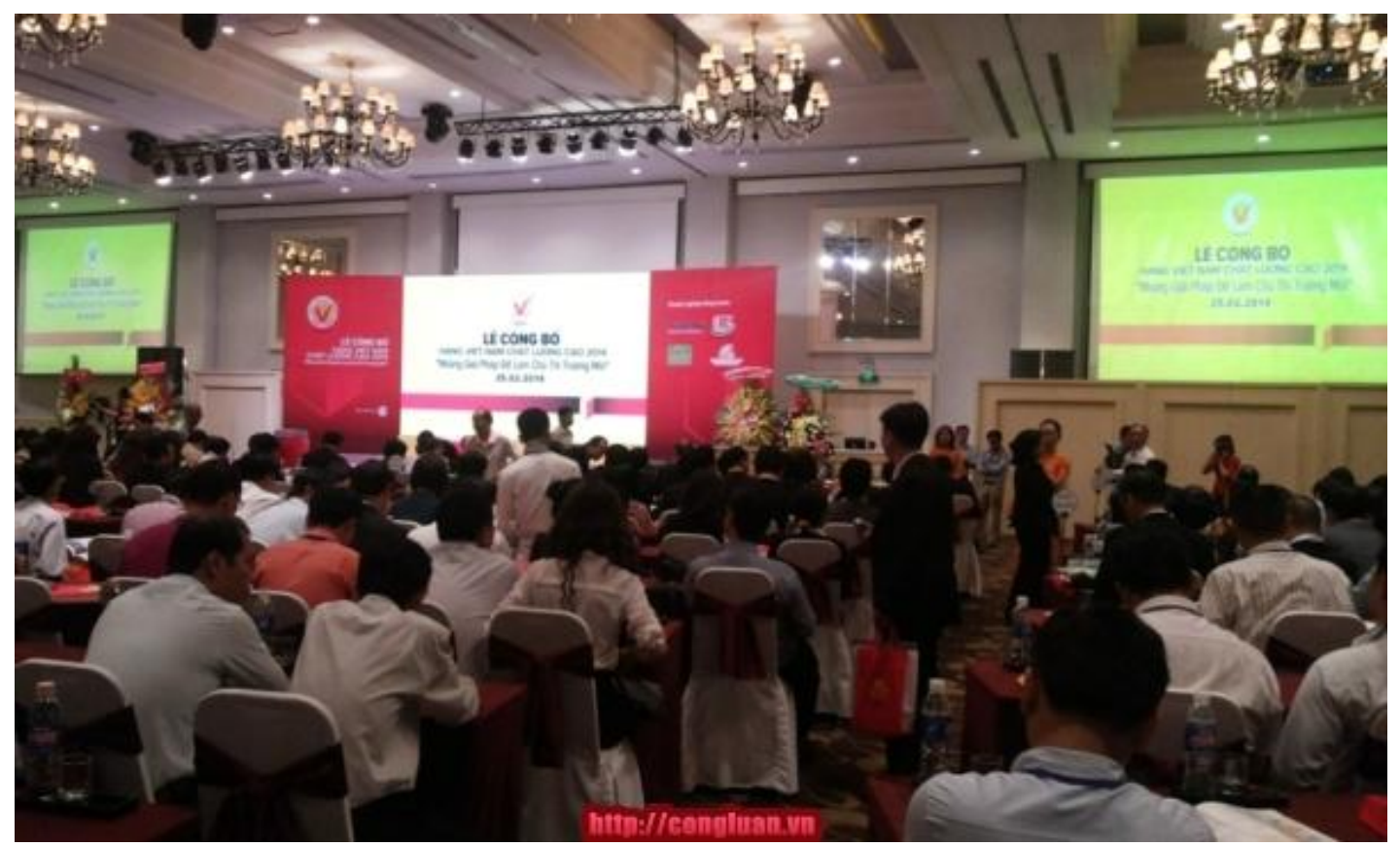

Quang cảnh buổi Lễ tôn vinh hàng Việt Nam

Ngoài sự có góp mặt của đại diện 476 doanh nghiệp được tôn vinh, buổi Lễ còn có sự tham dự của Bộ trưởng Bộ KH\&CN Nguyễn Quân, Phó Chủ tịch UBND TP.HCM Nguyễn Thị Hồng và nhiều lãnh đạo các Sở, ban, ngành, các Hội nghề nghiệp trong và ngoài nước.

Tại buổi lễ, sau khi trao danh hiệu cho những doanh nghiệp đạt HVNCLC năm 2014, Ban tổ chức còn tôn vinh 17 doanh nghiệp HVNCLC có thành tựu nổi bật trong lĩnh vực đổi mới sáng tạo, được Bộ trưởng Nguyễn Quân trao bằng khen. Bên cạnh đó, 42 doanh nghiệp 18 năm liên tiếp đạt danh hiệu HVNCLC cũng được ngợi khen khả năng giữ và phát huy được “đẳng cấp". 


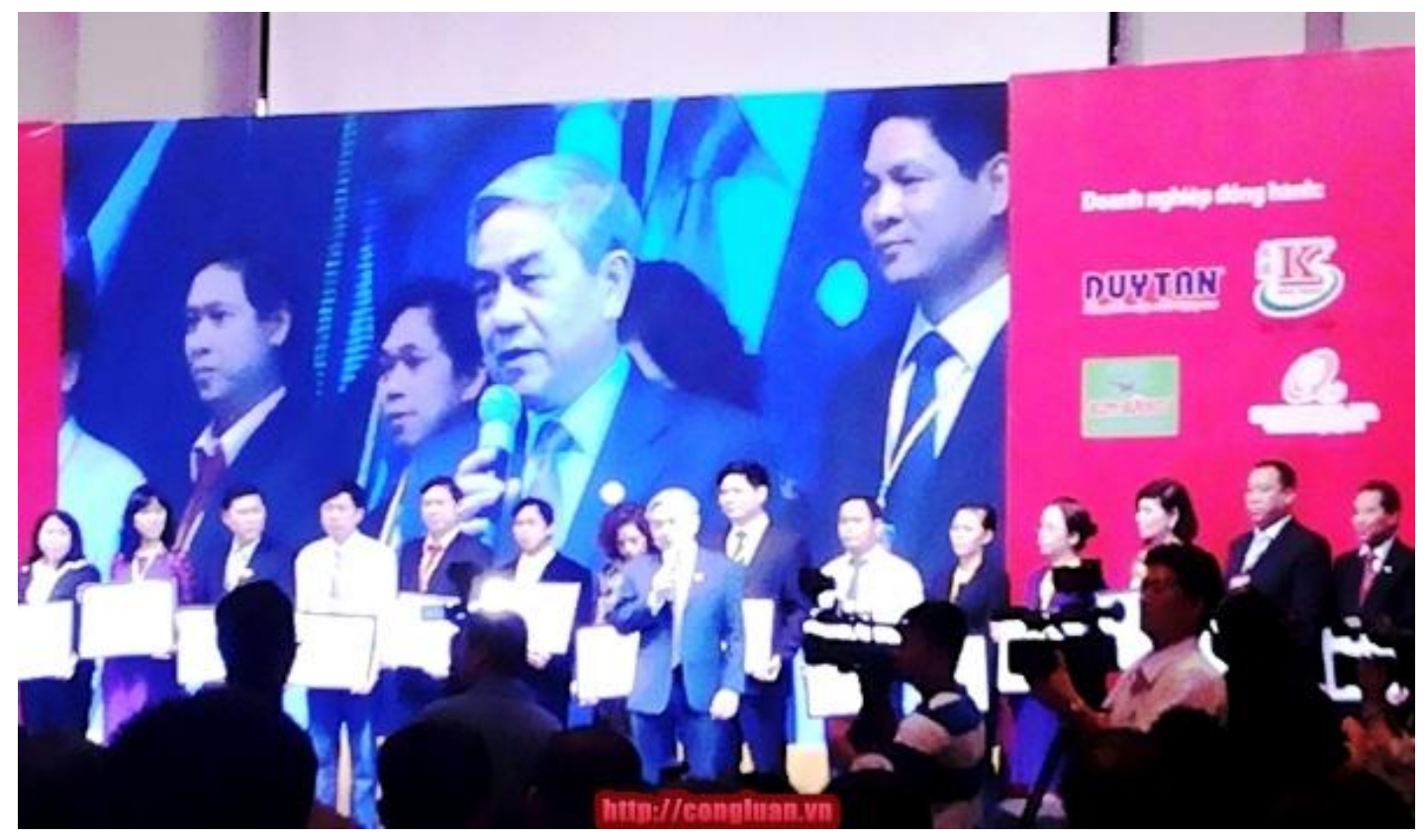

Bộ trương KH\&CN Nguyễn Quân trao Bằng khen cho 17 doanh nghiệp nổi bật về đổi mói sáng tạo.

Cũng trong khuôn khổ Lễ công bố, Ban tổ chức giải thưởng cũng giới thiệu kết quả sơ bộ của Đề án i2Metrix (Đề án khảo sát năng lực đổi mới - sáng tạo cạnh tranh của doanh nghiệp). Đây là đề án do trung tâm BSA và công ty nghiên cứu DHVP hợp tác phát triển, bước đầu triển khai trên các doanh nghiệp thành viên câu lạc bộ HVNCLC.

Dự kiến i2Metrix sẽ tiếp tục được nghiên cứu hoàn thiện, tiến hành triển khai trên quy mô lớn, trong những năm tiếp theo. Đồng thời, i2Metrix "made in Viet Nam” cũng sẽ được giới thiệu rộng rãi trong khu vực và thế giới.

\section{Hoàng Tuấn}


